\title{
Comparative study on the therapeutic effects of bone marrow mesenchymal stem cells versus platelet rich plasma on the pancreas of adult male albino rats with streptozotocin-induced type 1 diabetes mellitus
}

\author{
H. El-Haroun', R.M. Salama²(1) \\ ${ }^{1}$ Department of Histology, Faculty of Medicine, Menoufia University, Egypt \\ ${ }^{2}$ Department of Anatomy and Embryology, Faculty of Medicine, Menoufia University, Egypt
}

[Received: 12 November 2020; Accepted: 8 January 2021; Early publication date: 29 January 2021]

Background: The optimal treatment for autoimmune type 1 diabetes mellitus (T1DM) is endogenous regeneration of the pancreatic beta-cell. This can be achieved either by transplanting bone marrow mesenchymal stem cells (BMSCS) or injecting platelet-rich plasma (PRP). Current research reviewed a T1DM model and compared the effect of BMSCS on exocrine and endocrine pancreas portions versus PRP.

Materials and methods: Rats were divided into four groups: Control group, Diabetic group (single streptozotocin dose $60 \mathrm{mg} / \mathrm{kg} I P$ ), Diabetic + PRP group (PRP, $0.5 \mathrm{~mL} / \mathrm{kg}$ SC twice weekly/4 weeks given to diabetic rats) and Diabetic + BMSCs group (1 mL of PKH26 labelled MSCssuspension in buffer phosphatesolution, $3 \times 10^{6} \mathrm{cell} / \mathrm{s} / \mathrm{mL}$ $I V$ to diabetic rats). Glucose, amylase and lipase levels were calculated and pancreases were designed for light, electron microscopic, immunohistochemistry, morphometry and statistical analysis.

Results: Diabetic rats exhibited elevated glucose, decreased amylase and lipase compared to control rats. In addition, variable histological degenerative changes in the form of congested blood vessels have been identified with a significant increase in the mean area percentage of collagen, a significant decrease in the diameter of the islets, the number of cells in the islets of Langerhans and the number of zymogen granules. Ultrastructural findings exhibited distorted Golgi apparatus morphology, degenerated mitochondria, pyknotic nuclei, and few secretory beta-cell granules.

Conclusions: Administration of BMSCs to diabetic group significantly increased the number of cells and diameter of Langerhans islets and the number of zymogen granules compared to Diabetic group as well as Diabetic + PRP group. BMSCS could be considered more efficient than PRP in the treatment of type 1 diabetes. (Folia Morphol 2022; 81, 1: 65-81)

Key words: type 1 diabetes mellitus, streptozotocin, bone marrow mesenchymal stem cells, platelet-rich plasma, anti-insulin antibody 


\section{INTRODUCTION}

As a major health concern in the $21^{\text {st }}$ century, diabetes mellitus (DM) is a chronic metabolic disease causing hyperglycaemia; it is categorised into two major types (1 and 2). Type 1 diabetes mellitus (T1DM) is an autoimmune disease distinguished by an absolute insulin deficiency due to immune-mediated beta-cell-decimation of the islet pancreas [34]. Type 2 diabetes mellitus (T2DM) is distinguished by insulin resistance, reduced insulin production, and pancreatic beta-cell failure [44].

Diabetes has the potential to cause severe morbidity associated with microvascular damage and neuropathy affecting the retina, kidney, peripheral arteries and peripheral nerves due to numerous organ and body system complications [5, 10].

Insulin injections, hormone replacement, and oral hypoglycaemic drugs are main treatment choices for diabetic patients to stabilise their blood glucose [6] and to prevent deterioration of the condition [39]. However, these available treatments only manage symptoms or patient's condition and can only ameliorate hyperglycaemia [32]. Consequently, they are less effective in reversing insulin resistance, and in altering the progression of DM, and they do not prevent the progressive islet beta-cell degeneration, and cannot cure diabetes [27].

Another way of treatment was reliance on beta-cell renewal therapy utilising either the pancreas or the islet transplantation [46]. However, these procedures were constrained by risks of major invasive surgery, donor shortages and rejection complications [43].

Therefore, regeneration of the endogenous beta-cells would be the ideal therapeutic approach for DM control [36].

Platelet-rich plasma (PRP), other names, growth factor-rich plasma or autologous concentrated plas$\mathrm{ma}$ is now a low-cost procedure and has acted as an attractive area for clinicians and researchers over the two last decades in tissue repair [47]. PRP is an aggregation of the homologous platelets that is 3 to 5 times exceeding physiological constituent of thrombocytes suspended in a small volume of plasma in the entire blood [31]. Marx et al. [38] was the first to research PRP, suggested that plasma can only be called platelet-rich if the concentration of condensed platelets exceeds the baseline (150-400 thousand per microliter). For autologous plasma to have high healing properties, the platelet levels should be at least 1 million in $5 \mathrm{~mL}$ of plasma.
Growth factors (GFs) are among the innate biological peace-makers that have a role in regulating processes of tissue repair and regeneration, growth, and differentiation [35]. Platelets contain not only proteins needed for haemostasis but also convey many GFs [53], related to vasculature and tissue repair such as transforming growth factor (TGF), platelet-derived growth factor (PDGF), vascular endothelial growth factor (VEGF), epidermal growth factor (EGF), cytokines and insulin-like growth factor (IGF) [37].

Platelet-rich plasma can be used as an inexpensive technique for delivering high levels of homologous GFs [14]. It has been used in a number of medical and surgical specialties, including orthopaedics, neurosurgery, ophthalmology, maxillofacial surgery, cosmetic surgery and dentistry [58]. Nevertheless, there was a dearth of research that detected the influence of PRP injection on diabetic rat pancreas.

Mesenchymal stem cells (MSCs) have recently attracted considerable attention as a more promising method of treating DM. MSC are multipotent stem cells found in bone marrow, adipose tissue, umbilical cord blood and many other tissues. Such cells are used in regenerative medicine as they are capable of renewing themselves and differentiating into a wide range of cells and have a high capacity for cultural expansion [50, 59].

Stem cell transplantation can delay diabetes progression and prevent the complications of hyperglycaemia side effects and was successfully implemented in diabetes [62]. Similarly, bone marrow mesenchymal stem cells (BMSCs) transplant could retrieve pancreatic beta-cells and control blood glucose levels [42]. In addition, there are angiogenic, anti-apoptotic, anti-inflammatory and immunomodulatory effects [13].

The purpose of this study was to compare the impact of BMSCs and PRP on the biochemical and structural changes in the pancreas of adult male albino rats with streptozotocin (STZ)-induced T1DM in order to shed light on the potential for clinical use of such applications.

\section{MATERIALS AND METHODS}

\section{Animals}

In this study, 70 adult male albino rats were used, each weighing 180-200 g. The animals were purchased from and kept in the Medical Research Institute's animal house, Alexandria University, Egypt, and the experiment was carried out there. Until the beginning of the experiment, animals were housed in 


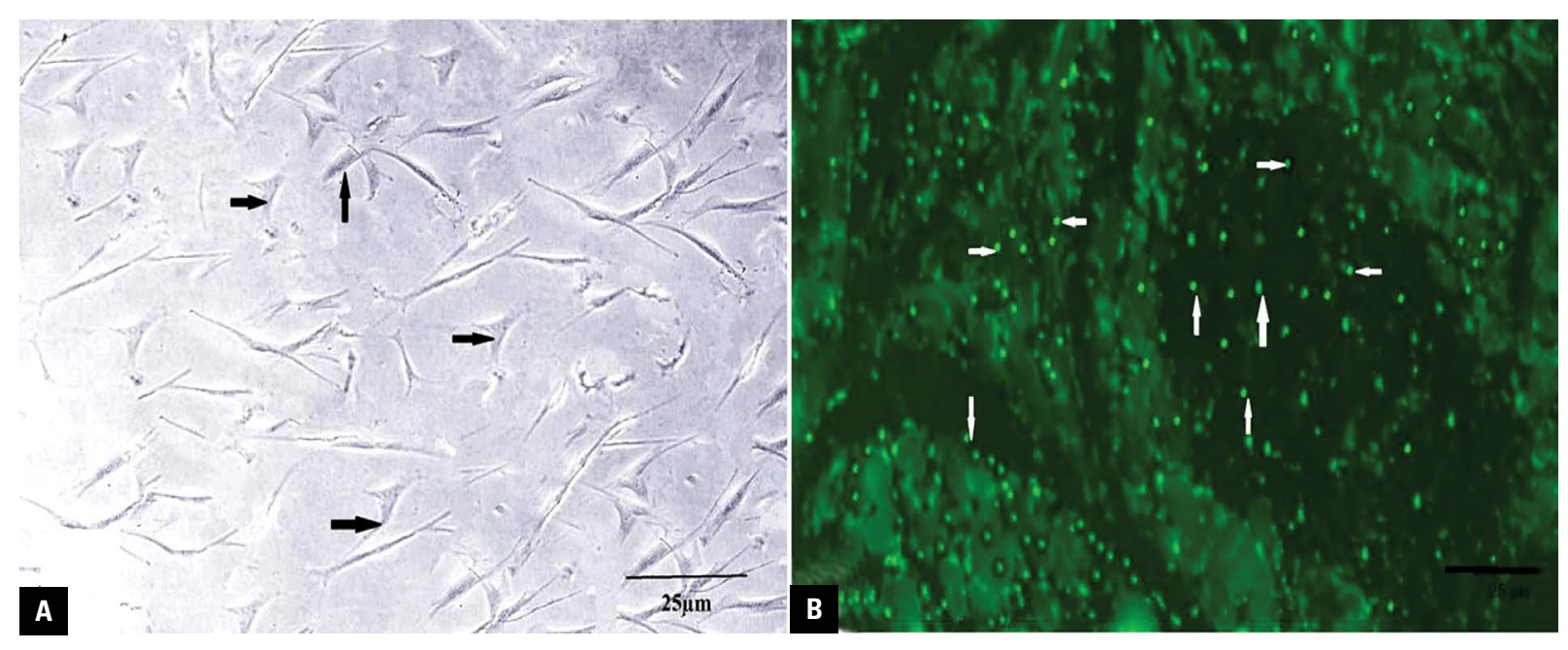

Figure 1. A. Ten-day culture, inverted microscope micrograph of bone marrow mesenchymal stem cells (BMSCs). The cells are adherent spindle-shaped cells; B. An image of a fluorescent microscope showing BMSCs labelled with fluorescent PKH67 appearing inside acini and pancreas islets as bright dots. Scale bar: $25 \mu \mathrm{m}$.

separate wire mesh cages and acclimatised at room temperature for 1 week, with a light and dark duration of 12:12, with access to food and water ad libitum. In this research, ethical principles for the treatment of animals were applied and monitored by an animal facility, Medical Research Institute, Alexandria University.

\section{Chemicals}

Streptozotocin (STZ): a vial of $1.5 \mathrm{~g}$ STZ powder and $220 \mathrm{mg}$ citric acid (Sigma Aldrich, Egypt), dissolved in $0.1 \mathrm{M}$ sodium citrate buffer $(\mathrm{pH} \mathrm{6})$ in accordance with the directions of manufacture and was used within 5 min of preparation.

\section{Platelet-rich plasma}

PRP preparation. At the Medical Research Institute's animal house, Alexandria University, Egypt, PRP was freshly prepared. The preparation method was accomplished by adjusting the protocol of the double centrifugation tube [48]. With the rats under ether anaesthesia, $2 \mathrm{~mL}$ of blood was collected from the retro-orbital plexus under sterilisation. The blood was submitted for 10 min centrifugation at 1600 revolutions/minute, resulting in 3 different layers; red blood cells below, white blood cells buffy coat in the middle, and plasma above. The plasma was then pipetted and the part over the buffy coat was gained. After that, the plasma was submitted for 10 min centrifugation at $2000 \mathrm{rpm}$, resulting in 2 portions: platelet poor plasma (PPP) above and platelet button at the bottom. To allow platelet resuspension, a portion of the PPP was removed and another portion remained with platelets that were slightly agitated. To verify the platelet concentration, $80 \mu \mathrm{L}$ of the PRP was counted in an automatic apparatus to ensure that the platelet number was greater than $1,000,000 / \mu \mathrm{L}$.

Finally, aspirate $0.5 \mathrm{~mL} / \mathrm{kg}$ PRP with micropipette and dissolute into the saline phosphate buffer (PBS) (PRP 1:1 PBS), and subcutaneously injected with a sterile insulin syringe.

\section{Bone narrow mesenchymal stem cells}

BM-MSCs (labelled PKH67; Green Fluorescent Cell Linker) were supplied from the stem cell research unit of the Department of Biochemistry of the Faculty of Medicine, Cairo University, Egypt. According to Augello et al. [9], BM-MSCs were harvested from the bone marrow of femurs and tibiae of 6 -week-old male rats.

In Dulbecco's Modified Eagle Medium (DMEM) purchased from Sigma, the isolated MSCs were cultured. $10 \%$ foetal calf serum (FCS) and $1 \% 100 \mathrm{U} / \mathrm{mL}$ penicillin, $100 \mathrm{mg} / \mathrm{mL}$ streptomycin and $2 \mathrm{mM} \mathrm{L-glu-}$ tamine were supplemented with DMEM. In humidified $\mathrm{CO}_{2}-5 \%$ air at $37^{\circ} \mathrm{C}$, the cells were cultured to confluence (80-90\%). Experiments were conducted on confluent cultures that were usually acquired on the $12^{\text {th }}$ to $14^{\text {th }}$ day of culture. In the next 3 passages, this process was repeated. For all experiments, cells at passage 3 were used. In vitro detection of MSCs was performed by culture research, using an inverted microscope (Olympus CKX53) to appear as spindle-shaped cells (Fig. 1A). 
The cells were centrifuged and washed twice in a serum-free medium prior to the experiment. Pancreatic tissue was studied with a fluorescent microscope (Olympus BX50F4, No. 7M03285, Tokyo, Japan) to detect and track PKH67-stained cells (Fig. 1B). The extracted cells in the third passage were labelled with the green fluorescent protein (PKH67-Sigma) [17].

\section{Induction of diabetes}

Overnight-fasted rats received a single intra-peritoneal (IP) injection of STZ (60 mg/kg body weight) dissolved in $0.1 \mathrm{M}$ sodium citrate buffer for T1DM induction. 48 hours after STZ injection (day 0 of experiment), animals were fasted overnight and blood samples were collected from the tail vein for glucose level monitoring. Rats are considered diabetic when glucose level exceeds $250 \mathrm{mg} / \mathrm{dL}$ [58].

\section{Experimental design}

In order to obtain PRP, 20 of the 70 male rats were used and the other 50 were randomly divided into four groups:

- Group I (Control group, $\mathrm{n}=20$ rats): four equal subgroups were subdivided into: (5 rats each):

- Subgroup la: rats were retained and acted as negative control without medication,

- Subgroup Ib: rats obtained an IP injection of a single $0.1 \mathrm{M}$ sodium citrate buffer,

- Subgroup Ic: rats were subcutaneously injected on a bi-weekly basis with PRP at a dose of $0.5 \mathrm{~mL} / \mathrm{kg}$ for 4 weeks,

- Subgroup Id: rats received $1 \mathrm{~mL}$ of PKH26 labelled MSC suspension in buffer phosphate solution $\left(3 \times 10^{6}\right.$ cells $/ \mathrm{mL}$ ) IV via tail vein [25] for 2 successive days;

- Group II (Diabetic group, $\mathrm{n}=10$ rats): a single STZ (60 $\mathrm{mg} / \mathrm{kg}$ body weight) IP injection dissolved in a $0.1 \mathrm{M}$ sodium citrate buffer was administered to rats;

- Group III (Diabetic + PRP group, $\mathrm{n}=10$ rats): PRP was administered bi-weekly to rats at a dose of $0.5 \mathrm{~mL} / \mathrm{kg}$ by SC injection for 4 weeks on day 0 following STZ diabetes induction assurance;

- Group IV (Diabetic + BMSCs group, $\mathrm{n}=10$ rats): $1 \mathrm{~mL}$ of PKH26-labeled MSC suspension in buffer phosphate solution was administered to rats on day 0 after induction of STZ diabetes for 2 consecutive days $\left(3 \times 10^{6}\right.$ cell $\left.\mathrm{s} / \mathrm{mL}\right) \mathrm{IV}$ via the tail vein [25].

\section{Biochemical study}

Blood samples collected from the tail vein of overnight fasting rats at the end of the $4^{\text {th }}$ week to measure.

Fasting glucose level, use one-touch Accu-Check glucometer and compatible blood glucose test strips, prior to grouping at the beginning of the experiment, all animals were subjected to blood glucose level measurement to ensure that they were normoglycaemic. Then, for the different sample types, the measuring method was conducted with statistical analysis.

Serum pancreatic amylase was performed by Landt et al. [33], an immunoabsorbent prepared by coating latex beads with a monoclonal antibody unique for pancreatic amylase. Serum pancreatic lipase was prepared by the enzyme-colorimetric method using Automated Hitachi Analyser [56].

\section{Experiments in histology, immunohistochemistry and electron microscopy}

Rats from all groups were sacrificed at the end of the $4^{\text {th }}$ week by being decapitated under light halothane anaesthesia. Pancreases were rapidly dissected out and divided into two parts: one for light microscopic examination and the other for electron microscopic examination.

Specimens subjected for light microscopic inspection were fixed in $10 \%$ formol saline for $24 \mathrm{~h}$ and subsequently processed for the preparation of $5-\mu \mathrm{m}$-thick paraffin sections for haematoxylin and eosin (H\&E) for histological validation [11], Mallory's trichrome stain for collagen fibre indication, and toluidine blue stain [57].

\section{Immunohistochemical study of anti-insulin antibody}

The immune-localisation technique was performed on pancreatic paraffin sections of $5 \mu \mathrm{m}$ thickness with the streptavidin-biotin-peroxidase staining method [15]. Anti-sera containing rat insulin polyclonal primary antibody (Bio-Genex, case no.: AR.295-R.) were then incubated with these parts for $1 \mathrm{~h}$. Dako-K0690; Dako Universal LSAB Kit (bio-tinylated secondary antibody) and Dako-K0690 (streptavidin horseradish peroxidase) were incubated in the components for $30 \mathrm{~min}$. Then, they were incubated with a 3,30-diaminobenzidine-4-hydrochloride (Sigma-D5905; Sigma Aldrich Company Ltd., Gillingham, UK) substrate 
Table 1. Biochemical reaction (fasting glucose level, serum amylase, serum lipase)

\begin{tabular}{|c|c|c|c|c|c|c|c|c|}
\hline & Control & Sodium citrate & PRP & BMSCs & STZ & STZ + PRP & STZ + BMSCs & $P$ value \\
\hline $\begin{array}{l}\text { Fasting blood } \\
\text { glucose }\end{array}$ & $80.7 \pm 3.2$ & $82.8 \pm 2.3$ & $80.8 \pm 2.78$ & $81.5 \pm 2.46$ & $414.6 \pm 17.61$ & $118.7 \pm 4.74$ & $82.3 \pm 4.03$ & $\begin{array}{l}\text { P1: } 0.153 ; \text { P2: } 0.95 ; \\
\text { P3: } 0.49 ; \text { P4: } 0.001^{* *} ; \\
\text { P5: } 0.001^{* *} ; \text { P6: } 0.38\end{array}$ \\
\hline $\begin{array}{l}\text { Serum } \\
\text { amylase }\end{array}$ & $63.1 \pm 2.77$ & $62.1 \pm 4.07$ & $62.4 \pm 2.63$ & $63.5 \pm 2.17$ & $31.9 \pm 2.85$ & $59.4 \pm 2.72$ & $61.5 \pm 1.78$ & $\begin{array}{c}\text { P1: } 0.45 ; \text { P2: } 0.41 ; \\
\text { P3: } 0.65 ; \text { P4: } 0.001^{* *} ; \\
\text { P5: } 0.004^{* *} ; \text { P6: } 0.11\end{array}$ \\
\hline $\begin{array}{l}\text { Serum } \\
\text { lipase }\end{array}$ & $85.3 \pm 4.45$ & $83 \pm 3.37$ & $86.5 \pm 2.46$ & $87.9 \pm 2.02$ & $36 \pm 2.87$ & $64.1 \pm 4.82$ & $84.3 \pm 6.52$ & $\begin{array}{l}\text { P1: 0.067; P2: 0.494; } \\
\text { P3: 0.119; P4: } 0.001^{* *} \text {; } \\
\text { P5: } 0.001^{* *} ; \text { P6: } 0.578\end{array}$ \\
\hline
\end{tabular}

**Highly significant difference: $p<0.001$. Data are shown as mean \pm standard deviation; BMSCs — bone marrow mesenchymal stem cells; PRP — platelet-rich plasma; STZ — streptozotocin; $\mathrm{P} 1$ = control vs. sodium citrate; $\mathrm{P} 2=$ control vs. PRP; $\mathrm{P3}=$ control vs. BMSCs; $\mathrm{P4}=$ control vs. STZ; P5 = control vs. STZ + PRP; P6 = control vs. STZ + BMSCs

package for 10 min to obtain the immune label. Lastly, the nuclei were stained by Harry's haematoxylin stain and a light microscope was used to examine the binding antibody [2].

\section{Morphometrical studies}

Using a light microscopic examination of the $\times 400$ images of the Mallory trichrome stain and anti-insulin antibody, the mean area percentage of collagen fibres and the number of insulin-positive beta-cells of all the animal groups were counted. By light microscopic inspection of the $\times 400 \mathrm{H} \& \mathrm{E}$, the diameter of the Langerhans islets was determined. Light microscope analyses of the toluidine blue stained section of $\times 400$ were used to count the number of zymogen granules. In the Department of Histology, Faculty of Medicine, Menoufia University (Leica Q 500 MC programme, Wechsler, Germany), all measurements were taken using the image analyser. Examinations in 10 high-power fields in each sample were carried out.

\section{Statistical studies}

The statistical analysis was conducted in the mean \pm standard error of mean (SEM) format using SPSS version 17 software (IBM Corporation, Somers, New York, USA). Using a one-way analysis of variance with post hoc analysis, the average of each group was compared with that of the other groups. In terms of chance, less than 0.01 at the $p$-value was the least significant quantity used.

\section{RESULTS}

\section{General observation}

Rats displayed normal behaviour in all groups, with the exception of excessive urination in diabetic rats, 2 days after the injection of STZ.

\section{Biochemical results}

Fasting blood glucose, serum lipase and amylase. In the control group, there was no significant difference between the rats (subgroups Ia, Ib, Ic, and Id). In the diabetic group, administration of STZ significantly increased blood glucose levels and decreased serum amylase and lipase levels relative to control rats $(p<0.001)$. Important rises in glucose levels and decreases in amylase and lipase levels in the Diabetic + PRP group were also observed relative to the Control group ( $p<0.001)$. PRP triggered a significant decrease in glucose and a rise in the amount of amylase and lipase, relative to the diabetic group $(p<0.001)$. The Diabetic + BMSCs group displayed negligible variations in contrast to the Control group (Table 1, Fig. 2A-C).

\section{Histological results}

The histological and immunohistochemical findings of all group I (Control group) subgroups were similar. So, group I (Control group) applied to them.

\section{Haematoxylin and eosin}

All control subgroups displayed regular pancreatic architecture; the gland is covered by a capsule of thin connective tissue that sends septae separating it into lobes and lobules. The pancreatic lobules were formed of crowded acini separated by thin connective tissue septa. Acinar cell cytoplasm revealed both basal basophilia and apical acidophilia. Langerhans islets appeared among pancreatic acini as lightly stained areas (Figs. 3A, 4A).

Diabetic group showed loss of normal lobular architecture with congested dilated blood vessels. Some acinar cells showed vacuolation with pyknosis of their nuclei. Islets of Langerhans showed multiple 

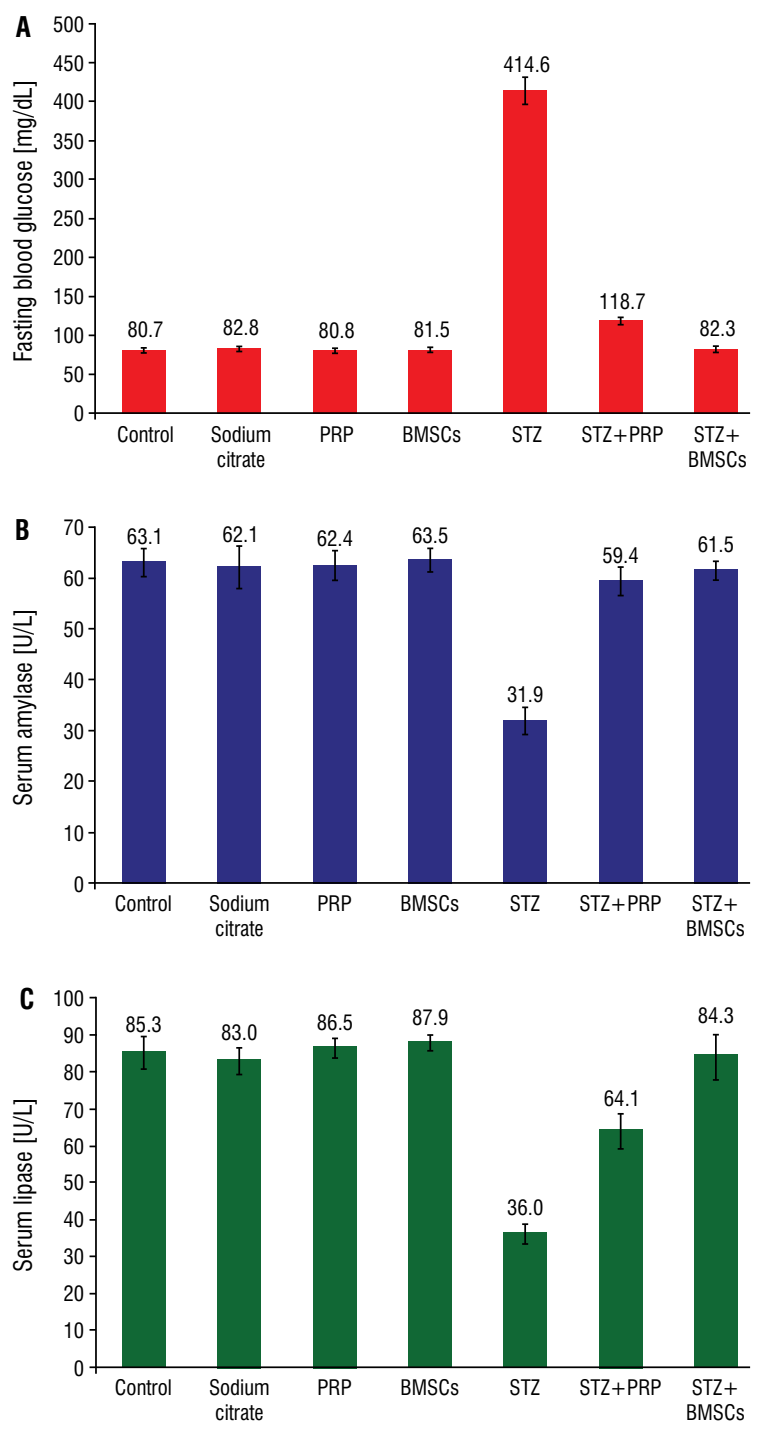

Figure 2. Fasting glucose (A), serum pancreatic amylase (B) and lipase levels (C) are illustrated in the graph; BMSCs - bone marrow mesenchymal stem cells; PRP — platelet-rich plasma; STZ - streptozotocin.

empty spaces, congested blood vessels and degenerative changes in some cells in the form of pyknosis of their nuclei and vacuolation of their cytoplasm (Figs. 3B, 4B).

Diabetic + PRP group pancreatic lobular architecture appeared almost identical to the Control group. However, there were still congested blood vessels and vacuolation of some acinar cells (Figs. 3C, 4C).

The group of Diabetic+ BMSCs displayed almost normal lobular pancreatic architecture. Acinar cells appeared in the nuclei of the vesicles. Normal Langerhans islet was found surrounded by normal acinar pancreatic tissue (Figs. 3D, 4D).

\section{Mallory's trichrome stain}

Sections of Control group showed thin connective tissue around blood vessels, in septae, in between pancreatic lobules and in islets of Langerhans (Fig. 5A).

Diabetic group showed excessive deposition of collagen fibres around thickened hypertrophied congested dilated blood vessels. Furthermore, islets of Langerhans showed massive deposition of collagen fibres (Fig. 5B).

The group treated with PRP showed moderate collagen fibres deposition between the pancreatic lobules (Fig. 5C). On the other hand, the injection of BMSCs showed a marked decrease in the value of collagen deposition (Fig. 5D).

\section{Toluidine reaction}

Sections of Control group showed abundant dark zymogen granules in the apical part of pancreatic acinar cells with normal features of their cells (Fig. 6A), while Diabetic group showed few apical zymogen granules in pancreatic acinar cells (Fig. 6B).

Meanwhile, PRP administration to diabetic rats (Diabetic + PRP group) induced an increase in number of zymogen granules in pancreatic acinar cells (Fig. 6C). Diabetic + BMSCs group showed normal distribution of zymogen granules in pancreatic acinar cells (Fig. 6D).

\section{Immunohistochemical results}

Strong positively stained insulin secretory granules of the beta-cells comprising the most common cell population of the islets were seen in sections of the control group (Fig. 7A).

Streptozotocin administration in diabetic group resulted in a decrease in the intensity of stained secretory granules of beta-cells, as well as a decrease in the number of cells and in the diameter of Langerhans islets (Fig. 7B).

Platelet-rich plasma administration to diabetic rats caused the positive stained secretory granules of beta-cells to increase moderately, primarily in the central core. There were also a few groups of unstained cells still present in the periphery of the islets (Fig. 7C).

The group of Diabetic + BMSCs displayed normal numbers of strong positively stained beta-cell secretory granules predominantly in the central core (Fig. 7D).

\section{Electron microscopic results}

With respect to electron microscopic results, subgroup la, Ib, Ic, and Id showed no significant difference, so they were represented as control group. 


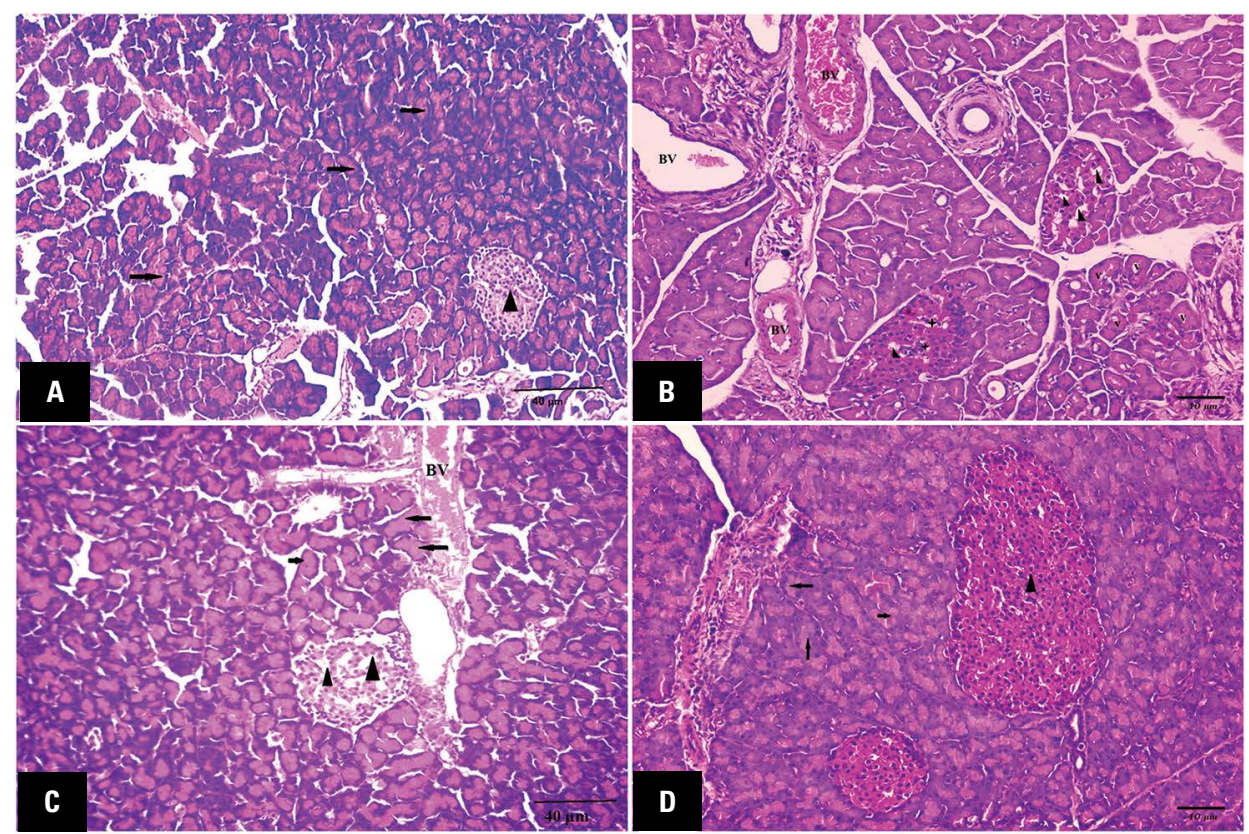

Figure 3. A. Stained pancreatic section of haematoxylin and eosin of the Control group showing pancreatic acinar cells (arrow). In between pancreatic acini, formed by cords of pale stained cells with foamy, the islet of Langerhans (arrow head) is also seen; B. Group II (Diabetic group) demonstrating congested dilated blood vessels (BV). Some acinar cells showed vacuolation (v) with their nuclei pyknosis. The Langerhans islets showed empty spaces (arrow head) and degenerative changes in some cells in the form of pyknotic nucleus and cytoplasm vacuolation (star); C. Group III (Diabetic + PRP group) showing congested blood vessels and certain acinar cells with pyknotic nucleus (arrow). The Langerhans Islets showed empty spaces (arrow head); D. Group IV (Diabetic + BMSCs group) reveals normal pancreatic lobular architecture. The acinar cells appear with vesicular nuclei (arrow). Normal pancreatic islet of Langerhans (arrow head) surrounded by normal pancreatic acini is seen. Scale bar: $40 \mu \mathrm{m}$.
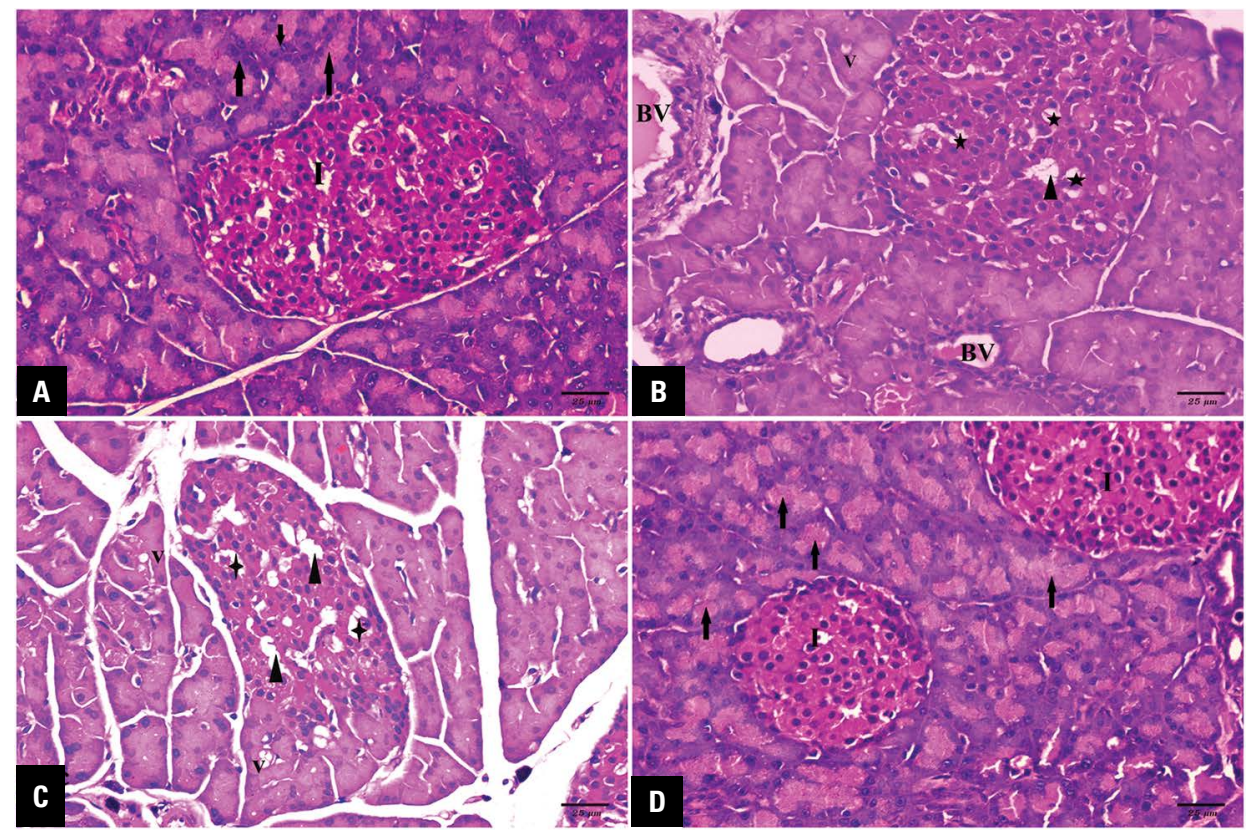

Figure 4. A. Stained pancreatic section haematoxylin and eosin of the Control group exhibiting pancreatic acinar cells appearing pyramidal with basal rounded vesicular nuclei (arrow). Between pancreatic acini, formed of cords of pale stained cells with foamy cytoplasm, the islet of Langerhans (I) is also seen; B. Group II (Diabetic group) showing dilated congested blood vessels (BV). Some acinar cells showed vacuolation (V) with their pyknotic nuclei. Langerhans islets showed empty spaces (arrow head) and degenerative changes in some cells in the form of cytoplasmic vacuolation (star); C. Group III (Diabetic + PRP group) showing vacuolation (v) of some acinar cells with pyknotic nucleus. The islets of Langerhans showed empty spaces in their cells (arrow head) and vacuolation (star); D. Group IV (Diabetic + BMSCs group) showing normal pancreatic lobular architecture, normal pancreatic islet of Langerhans (I) surrounded by normal pancreatic acini (arrow). Scale bar: $25 \mu \mathrm{m}$. 

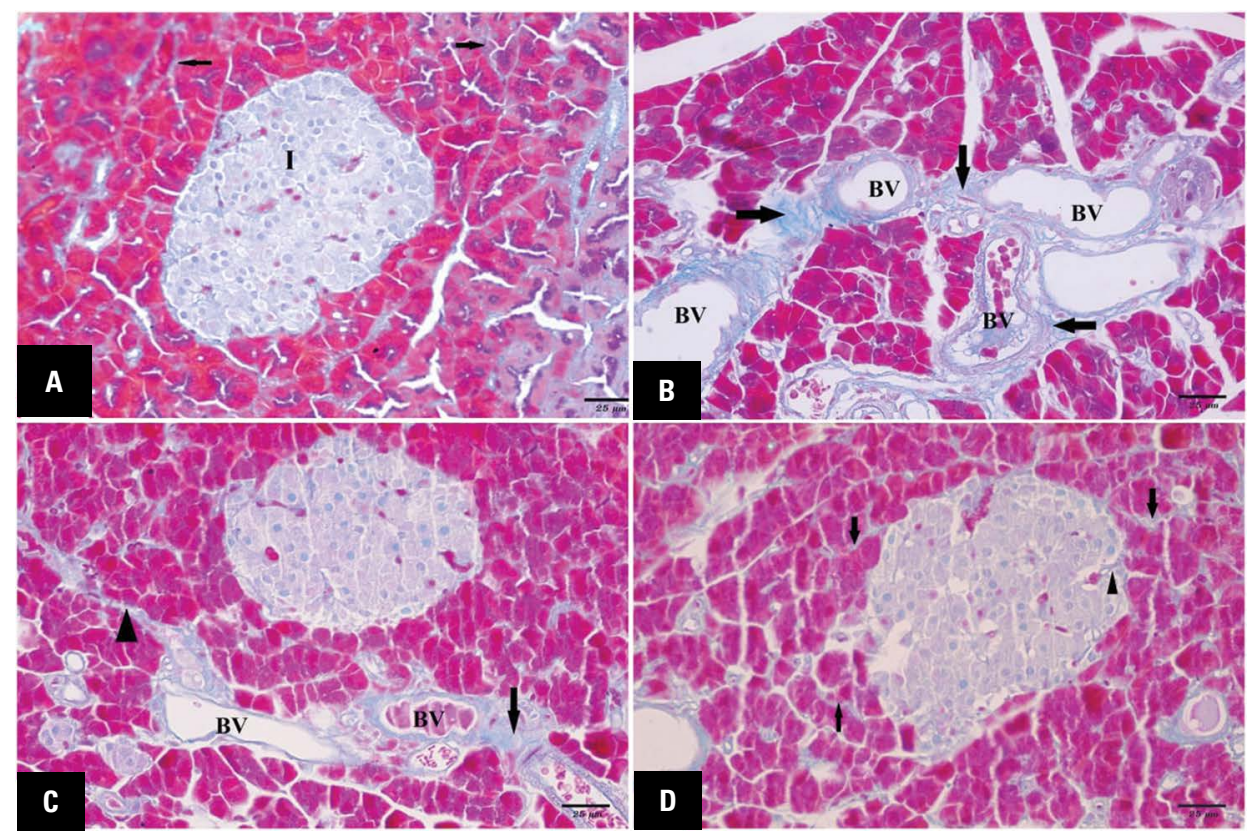

Figure 5. A. Mallory's trichrome stained portion of the control group pancreas showing thin connective tissue septae (arrow) between pancreatic acini and lobules; B. Group II (Diabetic group) exhibiting dilated blood vessels (BV) with large deposition of collagen fibres around blood vessels (arrow); C. Group III (Diabetic + PRP group) exhibiting mild deposition of collagen fibres between pancreatic acini (arrow head) and around blood vessels (arrow); D. Group IV (Diabetic + BMSCs group) exhibiting thin collagen fibres between pancreatic acini (arrow) and cells of islets of Langerhans (arrow head). Scale bar: $25 \mu \mathrm{m}$.
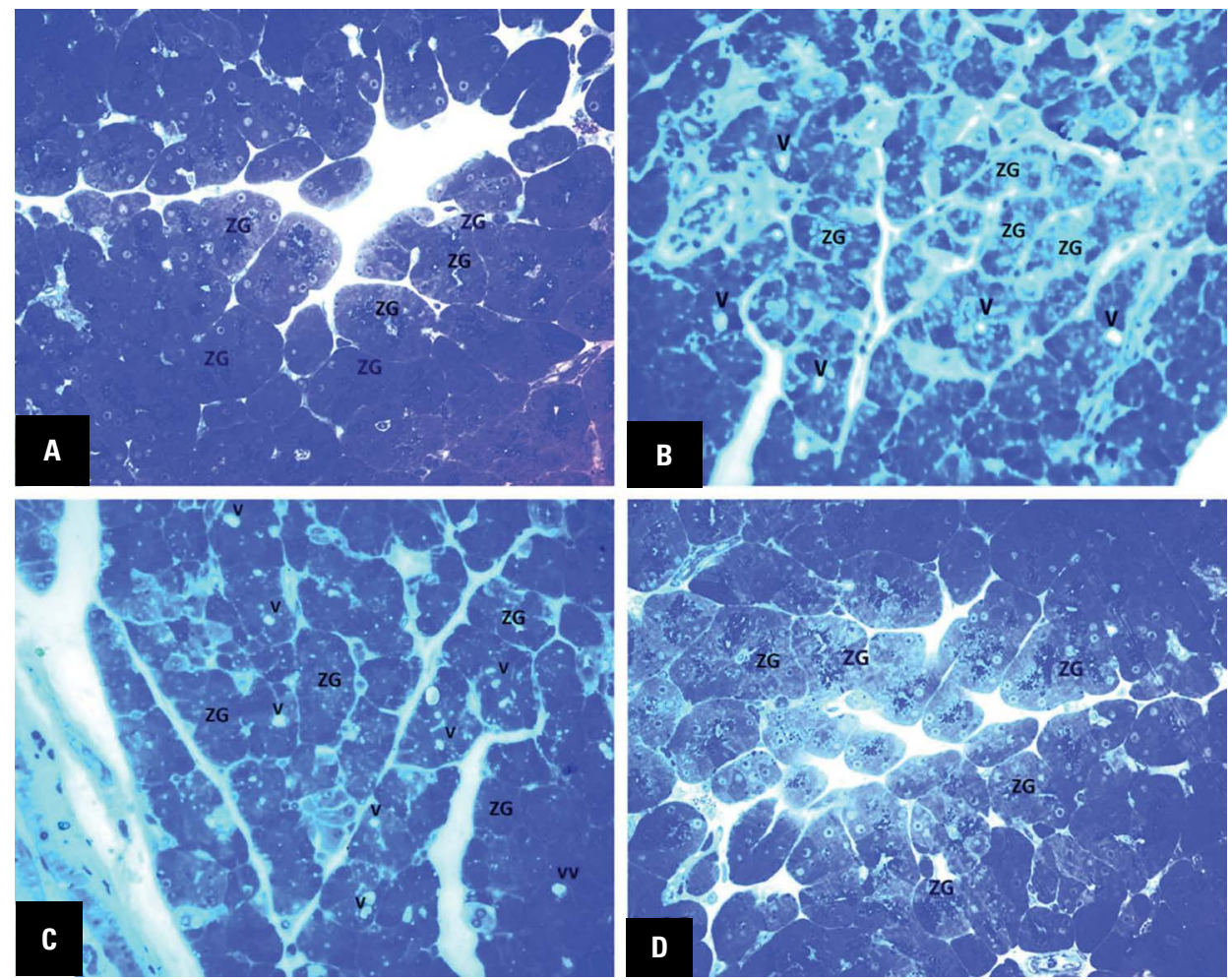

Figure 6. A. Toluidine blue stained pancreatic section of the control group displaying zymogen granules $(\mathrm{ZG})$ in the apical part of the pancreatic acini-lined cells; B. Group II (Diabetic group) showing few apical ZG in most pancreatic acini with multiple vacuoles (v); C. Group III (Diabetic + + PRP group) showing increase in number of apical ZG with several vacuolations (v) of their cytoplasm in most acinar cells; D. Group IV (Diabetic + BMSCs group) displaying ZG in the apical portion of the cells lining pancreatic acini. 


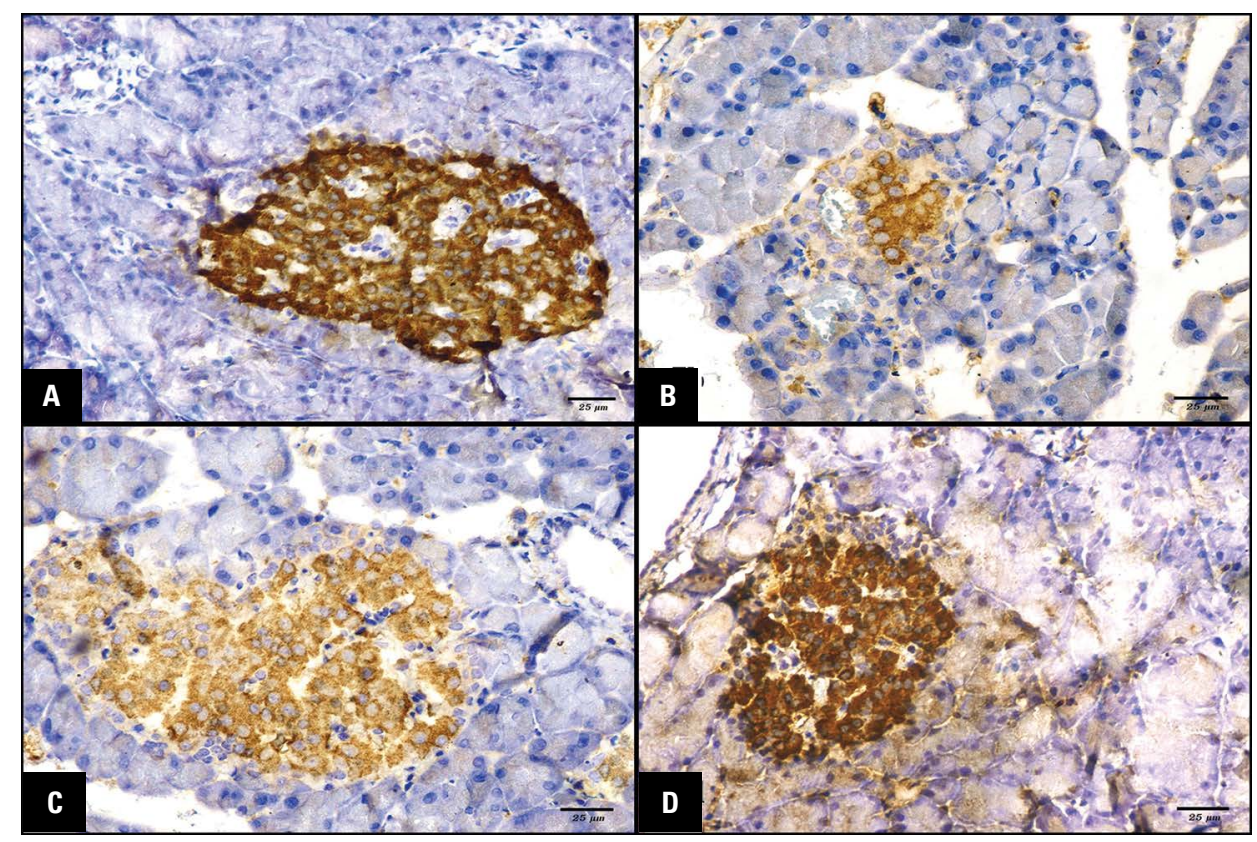

Figure 7. A. Pancreatic section stained anti-insulin antibodies of the control group exhibiting strong positively stained beta-cells for anti-insulin antibodies constituted by the main population of the Langerhans islet, leaving few central unstained cells; B. Group II (Diabetic group) with very few weak positive stained beta-cells exhibiting anti-insulin antibodies located mainly in the central part of the islet; C. Group III (Diabetic + + PRP group) with a moderate positive reaction of stained beta-cells to anti-insulin antibodies. The majority of unstained cell groups are located in the peripheral portion of the islet; D. Group IV (Diabetic + BMSCs group) showing strong positively stained beta-cells for anti-insulin antibodies which constitute the largest population of the Langerhans islet leaving few unstained central cells.

Pancreatic acinar cells with basal rounded vesicular nuclei and prominent nucleoli were shown by electron microscopic analysis of the control rat's pancreas. Acinar cells displayed packed cisterns of the rough endoplasmic reticulum (RER) and variable mitochondria in their cytoplasm. Apically, electron dense zymogen granules of variable sizes were located (Fig. 8A).

There were primarily beta-cells in the Langerhans islets. Many electron dense secretory granules surrounded by large lucent halo, mitochondria, and euchromatic nucleus accommodate their cytoplasm. Alpha-cell granules were small and electron dense (Fig. 8B).

Ultrathin sections of Diabetic group (group II) showed pancreatic acini with irregular electron dense nuclei, dilated RER, degenerated (balloon-shaped) mitochondria and phagosomes, some acinar cells were degenerated (Fig. 9A, B). Langerhans islets primarily contain beta-cells with few secretory granules displaying distorted Golgi apparatus morphology, degenerated mitochondria and pyknotic nucleus (Fig. 9C).

Platelet-rich plasma-treated rat pancreas (group III) with acinar cells displayed euchromatic nuclei surrounded by disrupted RER focal area and normal mitochondria (Fig. 10A). There are many electron dense secretory granules in the cytoplasm of islets beta-cells surrounded by large lucent halos, mitochondria, euchromatic nucleus, and mildly dilated Golgi cisternae (Fig. 10B).

As shown by the presence of regular pancreatic acinar cells, the pancreatic acini of the Diabetic + + BMSCs group showed marked improvement. Cytoplasm of acinar cells revealed regularly organised cisternae of RER, typical mitochondria and variable sized electron dense granules (Fig. 11A). The nuclei appeared vesicular and rounded. Cytoplasm beta-cells containing several dense electron secretory granules surrounded by wide lucent halos, mitochondria, and euchromatic nucleus were shown (Fig. 11B).

\section{Morphometric results}

Mean area percentage of collagen fibre deposition in pancreatic tissues. The Diabetic group (group II) reported a marked increase in the mean area percentage of pancreatic collagen deposition, which was significantly higher compared to the mean value of the control subgroups ( $l a, l b, I c$, and Id). The mean area percentage of collagen fibres displaying an increased value was seen in group III, which was statistically significant compared to the Control group ( $p>0.05$ ). 


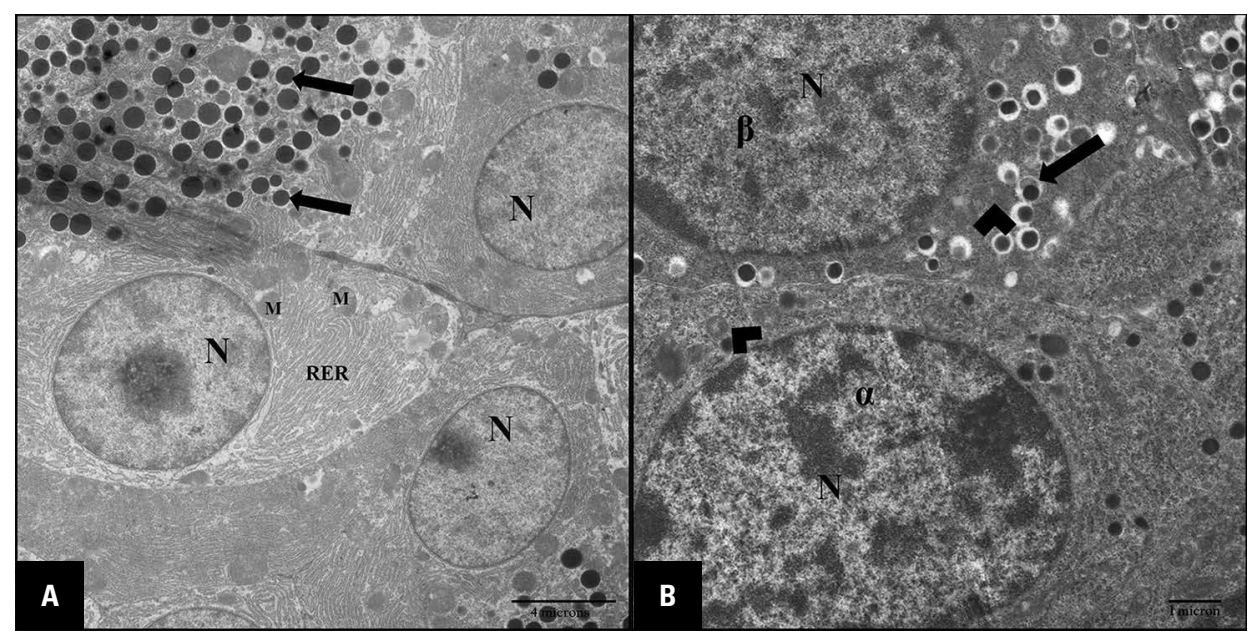

Figure 8. A. Group I (Control group) demonstrating acinar cells with euchromatic nuclei $(\mathrm{N})$ and many electron dense secretory granules (arrow) of variable size, more or less normal mitochondria $(\mathrm{M})$ and rough endoplasmic reticulum $(\mathrm{RER})(\times 8000)$; B. Group I (Control group) showing Langerhans islets incorporating beta-cells $(\beta)$ and alpha-cells $(\alpha)$. Many electron-dense secretory granules of beta-cells surrounded by a large light halo (arrow), mitochondria (arrow head), and euchromatic nucleus (N), while alpha-cell granules were small and electron-dense $(\times 17500)$.

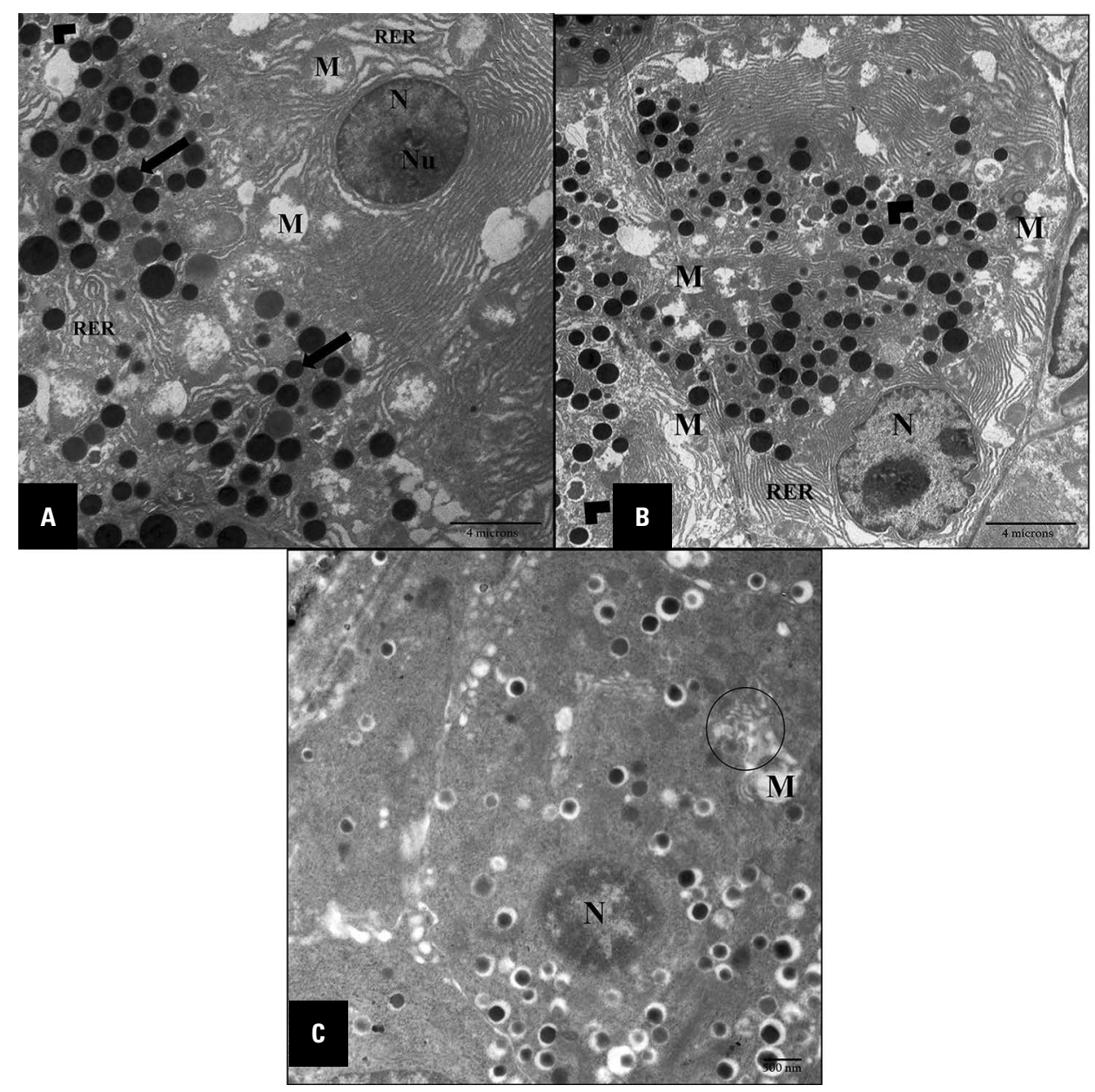

Figure 9. A. Group II (Diabetic group) displaying a large central nucleolus (Nu) hyperchromatic nucleus (N), massive dilated rough endoplasmic reticulum (RER), balloon-shaped mitochondria (M) and phagosomes (arrow head). Note the variable-sized apical secretory granules (arrow) ( $\times 8000$ ); B. Pancreatic acinar cells of group II (Diabetic group) with abnormal pancreatic acinar nucleus (N) surrounded by dilated rough endoplasmic reticulum (RER) with distorted mitochondria $(\mathrm{M})$ and phagosomes (arrow head) $(\times 8000)$; C. Group II (Diabetic group) Langerhans islets include distorted Golgi apparatus morphology (circle), degenerated mitochondria (M) and non-clear and swollen nuclear membrane $(\mathrm{N})$ of beta-cells $(\times 17500)$. 


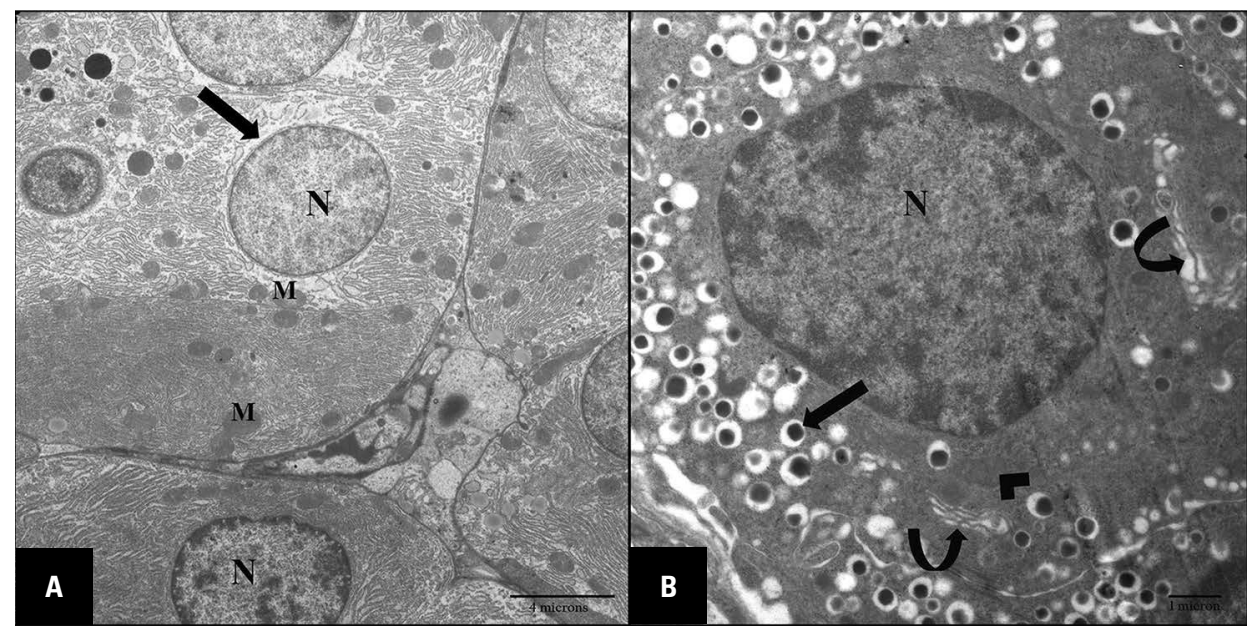

Figure 10. A. Group III (Diabetic + PRP group) showing euchromatic nucleus (N), acinar cells surrounded by focal disrupted rough endoplasmic reticulum (arrow), most likely normal mitochondria $(\mathrm{M})(\times 8000)$; B. Group III showing beta-cell-containing islets of Langerhans with several dense electron secretory granules surrounded by a large light halo (arrow), mitochondria (arrow head), euchromatic nucleus (N), and mildly dilated Golgi flattened vesicles (curved arrow) $(\times 17500)$.

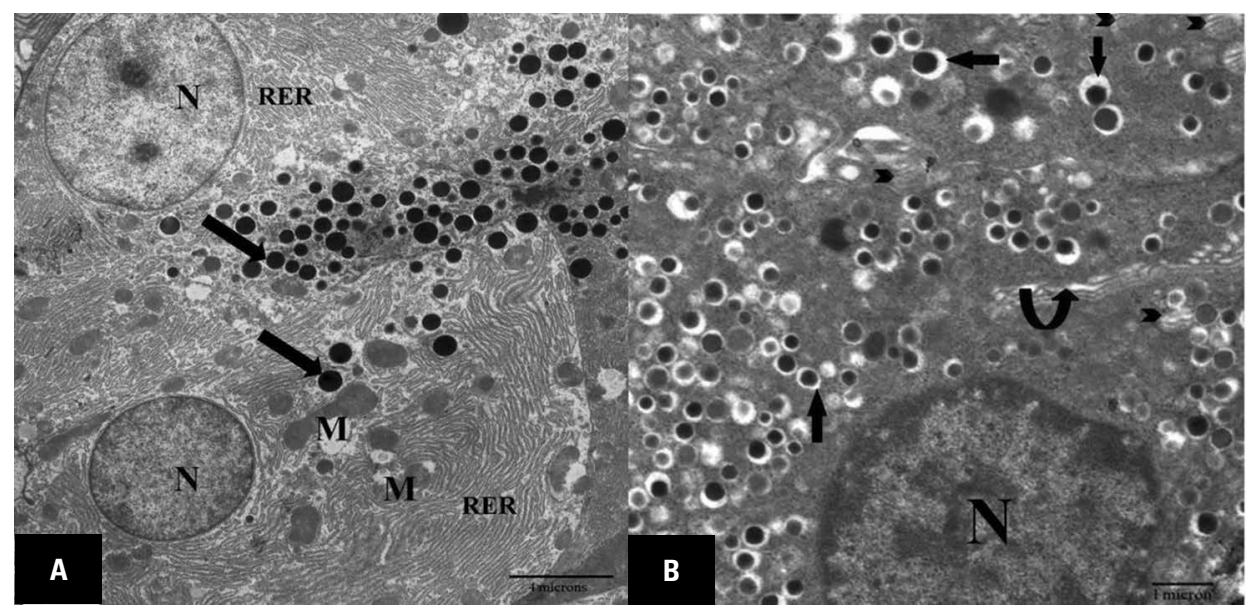

Figure 11. A. Group IV (Diabetic + BMSC group) displaying euchromatic nucleus (N) acinar cells and multiple electron dense secretory granules of variable size (arrow), mild degenerated mitochondria (M) and most likely regular rough endoplasmic reticulum $(\mathrm{RER})(\times 8000)$; B. Group IV (Diabetic + BMSCs group) showing Langerhans islets incorporate beta-cells with several dense secretory granules surrounded by a large light halo (arrow), mitochondria (arrow head) and euchromatic nucleus (N), normal Golgi apparatus morphology (curved arrow) $(\times 17500)$.

Group IV, on the other hand, displayed normal value with no noticeable difference relative to Control group.

Number of beta-cells/islet, diameter of islets and number of zymogen granules. In the control subgroups (Ia, Ib, Ic, and Id), there were no substantial variations between the rats in the number of cells of the Langerhans islets, the diameter of the Langerhans islets and the number of zymogen granules. The administration of STZ in the Diabetic group resulted in a substantial decrease in the number of cells of the Langerhans islets, in the diameter of the Langerhans islets, as well as in the number of gran- ules of zymogen. Meanwhile, the administration of PRP to diabetic rats (Diabetic + PRP group) has led to a significant decrease in the number of Langerhans islet cells, the diameter of Langerhans islets and the number of zymogen granules compared to the control group, and a significant increase in the number of Langerhans islet cells, the diameter of Langerhans islets and the number of zymogen granules compared to diabetic rats $(p<0.001)$.

The Diabetic + BMSCs group showed a noticeable increase in the number of Langerhans islet cells, the diameter of Langerhans islets and the number of zymogen 
Table 2. Morphometric results: number of beta-cells/islet, diameter of islets, number of zymogen granules and mean area percentage of collagen fibres

\begin{tabular}{|c|c|c|c|c|c|c|c|c|}
\hline & Control & Sodium citrate & PRP & BMSCs & STZ & STZ + PRP & STZ + BMSCs & $P$ value \\
\hline $\begin{array}{l}\text { Mean area } \\
\text { percentage of } \\
\text { collagen fibres }\end{array}$ & $8.21 \pm 0.66$ & 419 & $8.52 \pm 0.48$ & $8.41 \pm 0.55$ & $29.4 \pm 2.27$ & $20.6 \pm 2.07$ & $8.4 \pm 0.66$ & $\begin{array}{c}\text { P1: } 0.4 ; \text { P2: } 0.06 ; \\
\text { P3: } 0.13 ; \text { P4: } 0.001^{* *} ; \\
\text { P5: } 0.001^{* *} ; \text { P6: } 0.41\end{array}$ \\
\hline $\begin{array}{l}\text { Number of be- } \\
\text { ta-cells/islet }\end{array}$ & $212.9 \pm 3.14$ & $210.1 \pm 3.7$ & $210.7 \pm 2.1$ & $213.2 \pm 3.16$ & $75 \pm 4.29$ & $142.7 \pm 5.54$ & $215.8 \pm$ & $\begin{array}{c}\text { P1: 0.12; P2: } 0.06 ; \\
\text { P3: } 0.797 ; \text { P4: } 0.001^{* *} ; \\
\text { P5: } 0.001^{* *} ; \mathrm{P} 6: 0.046^{*}\end{array}$ \\
\hline $\begin{array}{l}\text { Diameter } \\
\text { of islets }\end{array}$ & $309.8 \pm 2.3$ & $305.9 \pm 5.4$ & $309.2 \pm 2.3$ & $312.1 \pm 2.96$ & $171 \pm 6.2$ & $219 \pm 6.6$ & $312.3 \pm 3.97$ & $\begin{array}{r}\text { P1: 0.037; P2: } 0.616 ; \\
\text { P3: } 0.102 ; P 4: 0.001^{* *} ; \\
\text { P5: } 0.001^{* *} ; P 6: 0.12\end{array}$ \\
\hline $\begin{array}{l}\text { Number of zymo- } \\
\text { gen granules }\end{array}$ & $53.1 \pm 2.77$ & $52.1 \pm 4.07$ & $52.4 \pm 2.63$ & $53.5 \pm 2.17$ & $23.9 \pm 5.7$ & $51.3 \pm 2.5$ & $52.9 \pm 1.85$ & $\begin{array}{c}\text { P1: } 0.45 ; \text { P2: } 0.41 ; \\
\text { P3: } 0.65 ; \text { P4: } 0.001^{* *} ; \\
\text { P5: } 0.15 ; \text { P6: } 0.81\end{array}$ \\
\hline
\end{tabular}

${ }^{*}$ Significant difference: $p<0.01 ;{ }^{* *}$ Highly significant difference: $p<0.001$. Data are shown as mean \pm standard deviation; BMSCs - bone marrow mesenchymal stem cells; PRP — platelet-rich plasma; STZ - streptozotocin; P1 = control vs. sodium citrate; P2 = control vs. PRP; P3 = control vs. BMSCs; P4 = control vs. STZ; P5 = control vs. STZ + PRP; $\mathrm{P} 6=$ control vs. STZ + BMSCs
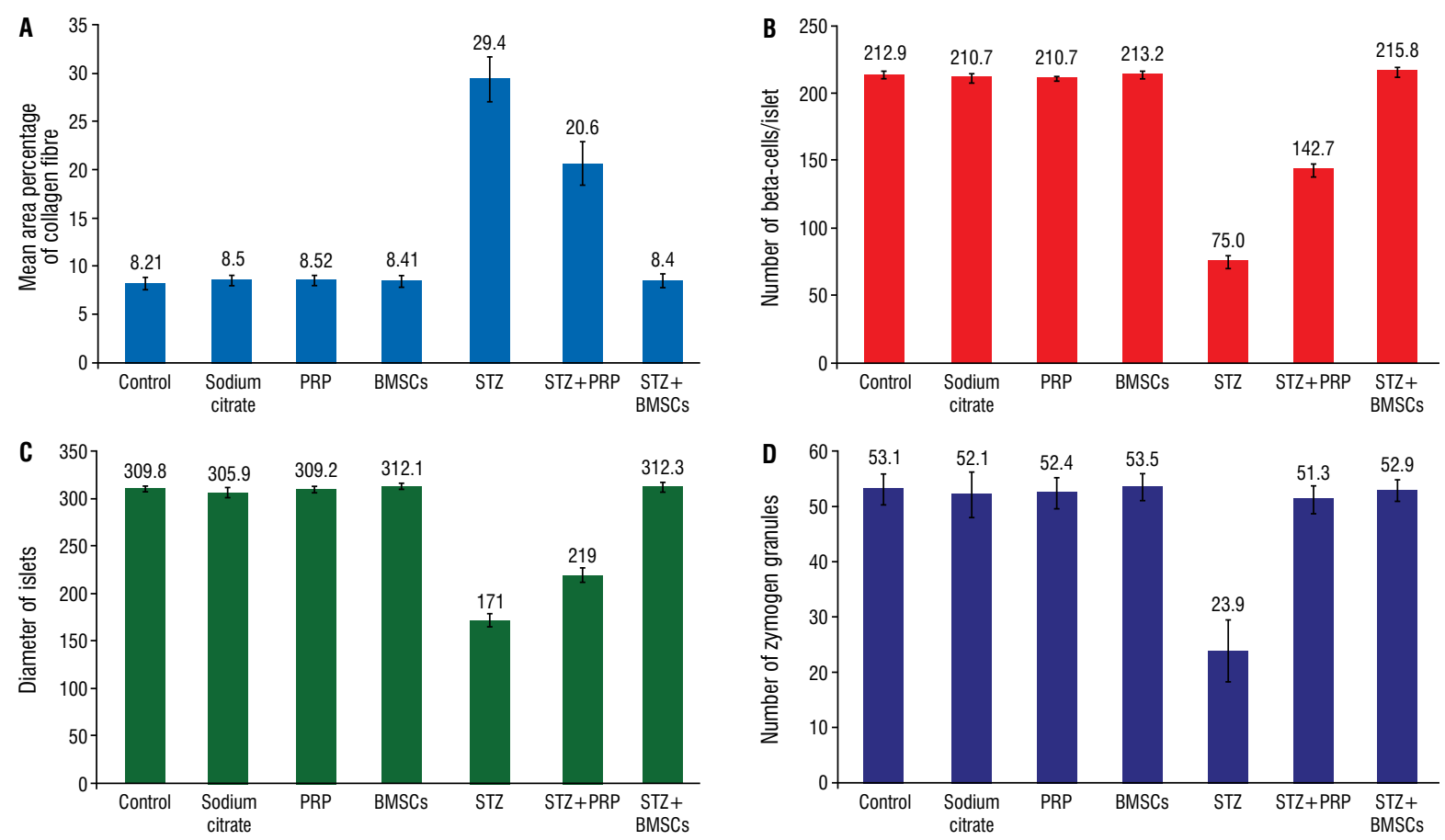

Figure 12. View graphs; A. Mean area percentage of collagen; B. Number of beta-cells/islet; C. Islet diameter; D. Number of granules of zymogen; BMSCs — bone marrow mesenchymal stem cells; PRP — platelet-rich plasma; STZ — streptozotocin.

granules $(p<0.001)$ compared to Diabetic and Diabetic + PRP groups, and showed an insignificant difference compared to the Control group (Table 2, Fig. 12A-D).

\section{DISCUSSION}

In this study, 48 hours after STZ administration, T1DM was induced when blood glucose levels exceeded $250 \mathrm{mg} / \mathrm{dL}$ [58]. This correlates with previous studies demonstrating that a single $60 \mathrm{mg} / \mathrm{kg}$ dose of
STZ can minimise the secretion of insulin and destruct pancreatic beta-cells in rats [3].

In this study, H\&E in the Diabetic group of exocrine pancreatic acini as well as the Langerhans islets showed loss of normal lobular architecture, congested dilated blood vessels, necrosis, vacuolation and apoptotic pyknotic nuclei.

These changes are close to the observations of the congested blood vessels and darkly stained pyknotic 
nuclei of some diabetic rat acinar cells $[41,45]$ that observed nearly all acinar cells in diabetic rats were swollen with small vacuoles. These results are consistent with Nurdiana et al. [41] that revealed histological destruction of the pancreatic islets of diabetic rats. Our findings coincide with Omar and Aboulkhair [45] who documented cell necrosis with congested blood capillaries, apoptosis in beta-cell of Langerhans and vacuolations in their cytoplasm. Ismail et al. [26] documented damage to the beta-cell of Langerhans due to STZ injection. Vacuolation has been described as one of the membrane permeability disorders that led to the transport of water and electrolytes into the cell. Significant cellular membrane damage resulting from lipid peroxidation mediating reactive oxygen species can be referred to as a permeability disorder [22].

The effect of STZ on the pancreas was explained by a decrease in cellular NAD+ and adenosine triphosphate (ATP) and an increase in the release of reactive oxygen species secondary to the passage of STZ through the cell membranes, causing alkylation and DNA damage, as well as the release of nitric oxide inside the cells which inhibits the action of aconitase, causing further DNA damage [3]. In addition, chronic diabetes hyperglycaemia contributes to increased development of oxygen-free radicals through glucose autoxidation, lipid peroxidation, and protein glycosylation, resulting in disruption of the oxidative/ anti-oxidative balance, resulting in oxidative stress and cellular harm in turn. These effects could result in the degeneration after STZ injection of islet beta-cells and pancreatic acinar cells [52].

The previous histological results of the destruction of islet beta-cells in the present study could explain the substantial increase in blood glucose levels and the apparent decrease in the number of Langerhans islet cells and the diameter of Langerhans islet cells in the diabetic group compared to the control group. This interpretation is agreed by others [40] who have explained that the drop in plasma insulin levels caused by selective pancreatic beta-cell necrosis is the cause of hyperglycaemia.

There was a decrease in serum amylase and lipase in the Diabetic group in this study.

These results are in agreement with Sano et al. [51] who documented damage to beta-cells with decreased synthesis of amylase and release from the exocrine pancreas of diabetic rats, pointing to the close connection between the endocrine and exocrine sections of the pancreas of the vascular network. In addition, marked decrease in amylase enzyme has been documented in STZ-diabetic mouse pancreatic acinar cells [4]. These findings suggest that the presence of insulin receptors on acinar cells is involved in the control of insulin function. In order to control cytosolic $\mathrm{Ca}^{2+}$ signals in acinar cells, ATP is well recognized and ATP production in acinar cells was inhibited by glucose metabolism in DM. Therefore, decreased cytosolic $\mathrm{Ca}^{2+}$ signals secondary to DM may be linked in reducing the secretion of digestive enzymes [30]. However, elevations in serum pancreatic amylase and lipase were reported for paediatric diabetic ketoacidosis [49].

Excessive deposition of collagen fibres was detected by Mallory's trichrome stain inspection of the Diabetic group. These results coincide with El-Desouki et al. [18] and Sorour et al. [55] that revealed increased collagen fibres around the islands of Langerhans, the pancreatic acini, the blood vessels and intercalated ducts in the diabetic group. Pancreatic fibrosis may be caused by pancreatic stellate cells (PSCs). Hyperglycaemia leads to the activation of PSCs in diabetes, resulting in fibrotic changes. In addition, stellate cell invasions of the pancreatic islets contribute to the destruction of fibrotic islets, resulting in a decline in beta-cell proliferation and a rush to apoptosis in diabetic patients [29]. Localised PSCs have begun to proliferate, morphologically turn into myofibroblast-like cells, and secrete components of the extracellular matrix once activated [8]. Moreover, collagen fibres were found allowing inadequate oxygen to enter the tissue, leading to degenerative changes and necrosis [3]. Furthermore, severe tissue damage following cytotoxic STZ-induced diabetes has caused lymphocytic depletion to increase reticular fibres [1].

Diabetic group showed few apical zymogen granules, which documented in agreement with other findings, that related decreased zymogen granules significantly to decrease serum amylase and acinar cell atrophy in diabetic rats [51]. Likewise, ultrastructural changes of acinar cells, such as electron dense nuclei, dilated RER, degenerated mitochondria and phagosomes, were detected. These findings agreed with others [18] that recorded dilatation and vesiculation of exocrine acinar cells with RER cisternae and mitochondrial disruption in diabetic rats due to disorganisation of cytoskeleton and integral proteins on the RER and the accumulation of iso-osmotic fluid in the injured cell. 
Langerhans islets beta-cells revealed degenerative changes such as distorted Golgi apparatus morphology, degenerated mitochondria and pyknotic nucleus with few secretory granules ultrastructurally. Similar findings have been documented in pancreatic beta-cells of diabetic rats with alloxan or STZ [28]. Moreover, El-Desouki et al. [18] showed that pancreatic beta-cells were degenerated with a pronounced decreased and breakdown of their granules. STZ caused damage to both the exocrine and endocrine portions of the pancreas. The most promising methods for the treatment of DM have recently been targeting the pancreatic beta-cell [60].

Current findings of the Diabetic + PRP group have shown an improvement in the histological picture of pancreatic islet cells and acini. These improvements have been confirmed by a decrease in blood glucose, increase in serum amylase and lipase levels with a modest increase in the amount of positively stained beta-cell secretory granules. These findings coincided with El-Tahawy et al. [19] who found improvement in the morphology of the pancreas, several healthy islets with an increase in the number of beta-cells, and a substantial decrease in blood glucose levels in the Diabetic + PRP treated group. The biological characteristics of PRP depend on the platelets concentration; convenient PRP preparations can provide high concentrations of many GFs, including IGF, EGF, and TGF $\beta$. PRP should contain at least one million platelets per microliter to be value for tissue repair [21]. GFs originated from PRP may be used as prospective therapies for diabetes as it can induce in vivo pancreatic beta-cell proliferation, regeneration and insulin production [36]. Moreover, a substantial elevation in GFs molecules, like VEGF, was noticed after treatment with a single dose of leukocyte-rich PRP [7]. In addition, Bonner-Weir et al. [12] clarified the production of new islet cells from progenitors in postnatal rodents via the neo-genesis process. Some cells derived from hormone progenitors present near the ducts in the adult pancreas and are transformed in adult mice into hormone-positive islet cells [63]. In both rodents and humans, endocrine cells can also be discovered in exocrine cells. Similarly, the long-term low dose administration of EGF induced beta-cell neogenesis in diabetic mice and resulted in ductal cell differentiation into beta-cells [64].

From the current study, it could be inferred that BMSCs could alleviate the degeneration of beta-cells and acinar cells induced by STZ. These findings were confirmed by the results of Omar and Aboulkhair [45] that showed normal histological structure of the Langerhans islets and the pancreatic acini with a substantial decrease in the mean random blood sugar level value, abundant positive insulin immunoreaction, with a significant increase in the mean area of islets beta-cells in the treated BMSCs group compared to the Diabetic group.

These assumptions in the histological and biochemical improvement of the Diabetic + BMSCs group in the current study were coincided with the findings that BMSCs have a crucial role in repairing injured tissues. They may differentiate, to replace the dead cells and to stimulate surrounding cells in the microenvironment, by secreting stimulant factors to boost the tissue repair process [61]. Consequently, BMSCs may be applied to treat tissue dysfunction in chronic hyperglycaemia. By replacing T1DM with either in vitro or in vivo differentiation, local microenvironment modulation by cytokines, chemokines and factors that promote endogenous regeneration, and by reducing or preventing autoimmunity of beta-cells, MSC transplantation may increase the mass of beta-cells [20]. Similarly, lanus et al. [24] found that the stem cells survived and differentiated into beta-cells resulting in an increase in the number and size of islets of Langerhans. Similarly, by observing normal blood glucose levels and neovascular formation after co-transplantation of pancreatic MSCs and islet mass, Sordi et al. [54] suggested the role of MSCs as helper cells. In comparison, other authors $[16,23]$ have found that the hyperglycaemic environment of diabetic patients reduces the proliferative capacity of MSCs, thus increasing cell apoptosis.

\section{CONCLUSIONS}

The present study reveals a model by STZ for T1DM. Promising treatments for diabetics are BMSCs and PRP. Their results are clearly visible. Due to their improved histological and ultrastructural protection of the pancreas and their ability to increase the number of cells in the islets of Langerhans, to decrease the amount of glucose and to increase serum amylase and lipase enzymes, the use of BMSCs may be more successful than PRP. PRP, however, is much less expensive than BMSC.

Conflict of interest: None declared 


\section{REFERENCES}

1. Abdel-Wahab MH, Abd-Allah AR. Possible protective effect of melatonin and/or desferrioxamine against streptozotocin-induced hyperglycaemia in mice. Pharmacol Res. 2000; 41(5): 533-537, doi: 10.1006/phrs.1999.0614, indexed in Pubmed: 10753552

2. Abdul-Hamid M, Moustafa N. Protective effect of curcumin on histopathology and ultrastructure of pancreas in the alloxan treated rats for induction of diabetes. J Basic Applied Zool. 2013; 66(4): 169-179, doi: 10.1016/j. jobaz.2013.07.003.

3. Abu-nasef SK, Amin HA, Abdel-Hamid GA. A histological and immunohistochemical study of beta cells in streptozotocin diabetic rats treated with caffeine. Folia Histochem Cytobiol. 2014; 52(1): 42-50, doi: 10.5603/ FHC.2014.0005, indexed in Pubmed: 24802960.

4. Akpan OU, Bassey RB, Agba BS, et al. Elevation of serum pancreatic amylase and distortion of pancreatic cyto-architecture in type 1 diabetes mellitus rats treated with Ocimum gratissimum. Niger Med J. 2014; 55(1): 34-38, doi: 10.4103/0300-1652.128157, indexed in Pubmed: 24970967.

5. Alshehri AM. Metabolic syndrome and cardiovascular risk. J Family Community Med. 2010; 17(2): 73-78, doi: 10.4103/1319-1683.71987, indexed in Pubmed: 21359028.

6. American Diabetes Association. Diagnosis and classification of diabetes mellitus. Diabetes Care. 2005; 28 (Suppl 1): S37-S42, doi: 10.2337/diacare.28.suppl_1.s37, indexed in Pubmed: 15618111.

7. Amy SW, Hillary B, Alex HS, et al. The systemic effects of platelet-rich plasma injection. Am J Sports Med. 2013; 41(1): 186-193, doi: 10.1177/0363546512466383, indexed in Pubmed: 23211708.

8. Apte M, Pirola R, Wilson J. New insights into alcoholic pancreatitis and pancreatic cancer. J Gastroenterol Hepatol. 2009; 24 Suppl 3: S51-S56, doi: 10.1111/j.14401746.2009.06071.x, indexed in Pubmed: 19799699.

9. Augello A, Kurth TB, De Bari C. Mesenchymal stem cells: a perspective from in vitro cultures to in vivo migration and niches. Eur Cell Mater. 2010; 20: 121-133, doi: 10.22203/ ecm.v020a11, indexed in Pubmed: 21249629.

10. Bainbridge KE, Hoffman HJ, Cowie CC. Diabetes and hearing impairment in the United States: audiometric evidence from the National Health and Nutrition Examination Survey, 1999 to 2004. Ann Intern Med. 2008; 149(1): 1-10, doi: 10.7326/0003-4819-149-1-200807010-00231, indexed in Pubmed: 18559825.

11. Bancroft JD, Layton C. Theory and practice of histological technique. 7th ed. Churchill Livingstone, London 2010: 173-214.

12. Bonner-Weir S, Li WC, Ouziel-Yahalom L, et al. Beta-cell growth and regeneration: replication is only part of the story. Diabetes. 2010; 59(10): 2340-2348, doi: 10.2337/ db10-0084, indexed in Pubmed: 20876724.

13. Cao M, Pan Q, Dong H, et al. Adipose-derived mesenchymal stem cells improve glucose homeostasis in high-fat diet-induced obese mice. Stem Cell Res Ther. 2015; 6: 208, doi: 10.1186/s13287-015-0201-3, indexed in Pubmed: 26519255.

14. Cavallo C, Roffi A, Grigolo B, et al. Platelet-rich plasma: the choice of activation method affects the release of bioactive molecules. Biomed Res Int. 2016; 2016: 6591717, doi: 10.1155/2016/6591717, indexed in Pubmed: 27672658.

15. Cemek M, Kağa $S$, Simşek $N$, et al. Antihyperglycemic and antioxidative potential of Matricaria chamomilla L. in streptozotocin-induced diabetic rats. J Nat Med. 2008; 62(3): 284-293, doi: 10.1007/s11418-008-0228-1, indexed in Pubmed: 18404309.

16. Cheng NC, Hsieh TY, Lai HS, et al. High glucose-induced reactive oxygen species generation promotes stemness in human adipose-derived stem cells. Cytotherapy. 2016; 18(3): 371-383, doi: 10.1016/j.jcyt.2015.11.012, indexed in Pubmed: 26780864.

17. Chudakov DM, Matz MV, Lukyanov S, et al. Fluorescent proteins and their applications in imaging living cells and tissues. Physiol Rev. 2010; 90(3): 1103-1163, doi: 10.1152/ physrev.00038.2009, indexed in Pubmed: 20664080.

18. El-Desouki NI, Basyony M, El-Nenaey M, et al. Histological and cytological studies on the effect of melatonin on experimentally induced pancreatic diabetes in rats. Egypt J Exp Biol (Zoo.). 2007; 3: 69-82.

19. El-Tahawy NF, Rifaai R, Saber $E$, et al. Effect of platelet rich plasma (PRP) injection on the endocrine pancreas of the experimentally induced diabetes in male albino rats: a histological and immunohistochemical study. J Diab Metab. 2017; 08(03), doi: 10.4172/2155-6156.1000730.

20. Ezquer M, Arango-Rodriguez M, Giraud-Billoud M. Mesenchymal stem cell therapy in type 1 diabetes mellitus and its main complications: from experimental findings to clinical practice. J Stem Cell Res Ther. 2014; 4(8), doi: 10.4172/2157-7633.1000227.

21. Gandhi A, Bibbo C, Pinzur M, et al. The role of platelet-rich plasma in foot and ankle surgery. Foot Ankle Clin. 2005; 10(4): 621-37, viii, doi: 10.1016/j.fcl.2005.06.009, indexed in Pubmed: 16297823.

22. Halliwell B, Chirico S. Lipid peroxidation: its mechanism, measurement, and significance. Am J Clin Nutr. 1993; 57(5 Suppl): 715S-724S; discussion 724S, doi: 10.1093/ ajcn/57.5.715S, indexed in Pubmed: 8475889 .

23. Hankamolsiri W, Manochantr S, Tantrawatpan C, et al. The effects of high glucose on adipogenic and osteogenic differentiation of gestational tissue-derived mscs. Stem Cells Int. 2016; 2016: 9674614, doi: 10.1155/2016/9674614, indexed in Pubmed: 27057179.

24. lanus A, Holz GG, Theise ND, et al. In vivo derivation of glucose-competent pancreatic endocrine cells from bone marrow without evidence of cell fusion. J Clin Invest. 2003; 111(6): 843-850, doi: 10.1172/JCl16502, indexed in Pubmed: 12639990.

25. Isik AT, Celik T, Ural AU, et al. Mesenchymal stem cell therapy for the streptozotocin-induced neurodegeneration in rats. Neurol Res. 2016; 38(4): 364-372, doi: 10.1080/01616412.2016.1139292, indexed in Pubmed: 27078696.

26. Ismail ZM, Kamel AM, Yacoub MF, et al. The effect of in vivo mobilization of bone marrow stem cells on the pancreas of diabetic albino rats (a histological \& immunohistochemical study). Int J Stem Cells. 2013; 6(1): 1-11, doi: 10.15283/ ijsc.2013.6.1.1, indexed in Pubmed: 24298369.

27. Kahn S, Cooper M, Del Prato S. Pathophysiology and treatment of type 2 diabetes: perspectives on the past, present, and future. Lancet. 2014; 383(9922): 1068-1083, doi: 10.1016/s0140-6736(13)62154-6. 
28. Kanter M, Uysal H, Karaca T, et al. Depression of glucose levels and partial restoration of pancreatic beta-cell damage by melatonin in streptozotocin-induced diabetic rats. Arch Toxicol. 2006; 80(6): 362-369, doi: 10.1007/s00204005-0055-z, indexed in Pubmed: 16341692.

29. Kim JW, Ko SH, Cho JH, et al. Loss of beta-cells with fibrotic islet destruction in type 2 diabetes mellitus. Front Biosci. 2008; 13: 6022-6033, doi: 10.2741/3133, indexed in Pubmed: 18508639.

30. Kluge R, Scherneck S, Schürmann A, et al. Pathophysiology and genetics of obesity and diabetes in the New Zealand obese mouse: a model of the human metabolic syndrome. Methods Mol Biol. 2012; 933: 59-73, doi: 10.1007/978-162703-068-7_5, indexed in Pubmed: 22893401.

31. Knezevic NN, Candido KD, Desai R, et al. Is platelet-rich plasma a future therapy in pain management? Med Clin North Am. 2016; 100(1): 199-217, doi: 10.1016/j. mcna.2015.08.014, indexed in Pubmed: 26614728.

32. Lambrinoudaki I, Vlachou SA, Creatsas G. Genetics in gestational diabetes mellitus: association with incidence, severity, pregnancy outcome and response to treatment. Curr Diabetes Rev. 2010; 6(6): 393-399, doi: 10.2174/157339910793499155, indexed in Pubmed: 20879971.

33. Landt M, Hortin GL, Smith $\mathrm{CH}$, et al. Rapid measurement of serum pancreatic amylase. J Clin Lab Anal. 1994; 8(1): 10-15, doi: 10.1002/jcla.1860080104, indexed in Pubmed: 7513020 .

34. Maahs DM, West NA, Lawrence JM, et al. Epidemiology of type 1 diabetes. Endocrinol Metab Clin North Am. 2010; 39(3): 481-497, doi: 10.1016/j.ecl.2010.05.011, indexed in Pubmed: 20723815.

35. Mani R, Mahantesha S, Nandini S, et al. Growth factors in periodontal regeneration. J Adv Oral Res. 2018; 5(2): 1-5, doi: 10.1177/2229411220140201.

36. Márquez-Aguirre AL, Canales-Aguirre AA, Padilla-Camberos E, et al. Development of the endocrine pancreas and novel strategies for beta-cell mass restoration and diabetes therapy. Braz J Med Biol Res. 2015; 48(9): 765-776, doi: 10.1590/1414-431X20154363, indexed in Pubmed: 26176316.

37. Marx RE. Platelet-rich plasma: evidence to support its use. J Oral Maxillofac Surg. 2004; 62(4): 489-496, doi: 10.1016/j. joms.2003.12.003, indexed in Pubmed: 15085519.

38. Marx RE, Carlson ER, Eichstaedt RM, et al. Platelet-rich plasma: growth factor enhancement for bone grafts. Oral Surg Oral Med Oral Pathol Oral Radiol Endod. 1998; 85(6): 638-646, doi: 10.1016/s1079-2104(98)90029-4, indexed in Pubmed: 9638695.

39. Monnier L, Colette C, Dunseath GJ, et al. The loss of postprandial glycemic control precedes stepwise deterioration of fasting with worsening diabetes. Diabetes Care. 2007; 30(2): 263-269, doi: $10.2337 / \mathrm{dc0} 06-1612$, indexed in Pubmed: 17259492.

40. Najafian M, Jahromi MZ, Nowroznejhad MJ, et al. Phloridzin reduces blood glucose levels and improves lipids metabolism in streptozotocin-induced diabetic rats. Mol Biol Rep. 2012; 39(5): 5299-5306, doi: 10.1007/s11033011-1328-7, indexed in Pubmed: 22167331.

41. Nurdiana S, Goh YM, Ahmad H, et al. Changes in pancreatic histology, insulin secretion and oxidative status in diabetic rats following treatment with Ficus deltoidea and vitexin. BMC Complement Altern Med. 2017; 17(1): 290, doi: 10.1186/s12906-017-1762-8, indexed in Pubmed: 28576138.

42. Oh SH, Muzzonigro TM, Bae SH, et al. Adult bone marrow-derived cells trans-differentiating into insulin-producing cells for the treatment of type I diabetes. Lab Invest. 2004; 84(5): 607-617, doi: 10.1038/labinvest.3700074, indexed in Pubmed: 15034596.

43. Okere B, Lucaccioni L, Dominici M, et al. Cell therapies for pancreatic beta-cell replenishment. Ital J Pediatr. 2016; 42(1): 62, doi: 10.1186/s13052-016-0273-4, indexed in Pubmed: 27400873.

44. Olokoba AB, Obateru OA, Olokoba LB. Type 2 diabetes mellitus: a review of current trends. Oman Med J. 2012; 27(4): 269-273, doi: 10.5001/omj.2012.68, indexed in Pubmed: 23071876.

45. Omar A, Aboulkhair A. Effect of bone marrow versus adipose tissue derived mesenchymal stem cells on the pancreas of streptozotocin-induced diabetes mellitus type $\mathrm{i}$ in adult male rats (histological study). Egypt J Histol. 2017; 40(1): 12-24, doi: 10.21608/ejh.2017.3693.

46. Pagliuca FW, Millman JR, Gürtler M, et al. Generation of functional human pancreatic beta cells in vitro. Cell. 2014; 159(2): 428-439, doi: 10.1016/j.cell.2014.09.040, indexed in Pubmed: 25303535.

47. Pavlovic V, Ciric M, Jovanovic V, et al. Platelet rich plasma: a short overview of certain bioactive components. Open Med (Wars). 2016; 11(1): 242-247, doi: 10.1515/med2016-0048, indexed in Pubmed: 28352802.

48. Pazzini J, De Nardi AB, Huppes RR, et al. Method to obtain platelet-rich plasma from rabbits (Oryctolagus cuniculus). Pesq Vet Bras. 2016; 36(1): 39-44, doi: 10.1590/s0100$736 \times 2016000100007$.

49. Quiros JA, Marcin JP, Kuppermann N, et al. Elevated serum amylase and lipase in pediatric diabetic ketoacidosis. Pediatr Crit Care Med. 2008; 9(4): 418-422, doi: 10.1097/ PCC.0b013e318172e99b, indexed in Pubmed: 18496406.

50. Ren H, Sang $Y$, Zhang F, et al. Comparative analysis of human mesenchymal stem cells from umbilical cord, dental pulp, and menstrual blood as sources for cell therapy. Stem Cells Int. 2016; 2016: 3516574, doi: 10.1155/2016/3516574, indexed in Pubmed: 26880954.

51. Sano T, Ozaki K, Matsuura T, et al. Giant mitochondria in pancreatic acinar cells of alloxan-induced diabetic rats. Toxicol Pathol. 2010; 38(4): 658-665, doi: 10.1177/0192623310368982, indexed in Pubmed: 20448086.

52. Sheweita SA, Mashaly S, Newairy AA, et al. Changes in oxidative stress and antioxidant enzyme activities in streptozotocin-induced diabetes mellitus in rats: role of alhagi maurorum extracts. Oxid Med Cell Longev. 2016; 2016: 5264064, doi: $10.1155 / 2016 / 5264064$, indexed in Pubmed: 26885249.

53. Sonker A, Dubey A, Bhatnagar A, et al. Platelet growth factors from allogeneic platelet-rich plasma for clinical improvement in split-thickness skin graft. Asian J Transfus Sci. 2015; 9(2): 155-158, doi: 10.4103/0973-6247.162712, indexed in Pubmed: 26420935.

54. Sordi V, Melzi R, Mercalli A, et al. Mesenchymal cells appearing in pancreatic tissue culture are bone marrow-derived stem cells with the capacity to improve transplanted 
islet function. Stem Cells. 2010; 28(1): 140-151, doi: 10.1002/stem.259, indexed in Pubmed: 19924826.

55. Sorour H, Selim m, EL-Moselhy LS, et al. Ameliorative effect of watermelon rind ingestion on the pancreas of diabetic female albino rat (histological, immunohistochemical and morphometric study). Egypt J Histol. 2019; 42(1): 10-22, doi: 10.21608/ejh.2018.4243.1018.

56. Stoytcheva M, Montero G, Zlatev R, et al. Analytical Methods for Lipases Activity Determination: A Review. Curr Analyt Chem. 2012; 8(3): 400-407, doi: 10.2174/ 157341112801264879.

57. Suvarna K, Layton $\mathrm{CH}$, Bancroft J. Bancroft's theory and practice of histological techniques. 8th ed. Churchill Livingstone, Philadelphia 2013: 373-391.

58. Ukwenya V, Ashaolu O, Adeyemi D, et al. Experimental diabetes and the epididymis of Wistar rats: The protective effects of Anacardium occidentale (Linn.). J Exp Clini Anat. 2015; 14(2): 57, doi: 10.4103/1596-2393.177029.

59. Van Pham P, Vu NB, Phan N. Umbilical cord-derived stem cells (ModulatistTM) show strong immunomodulation capacity compared to adipose tissue-derived or bone marrow-derived mesenchymal stem cells. Biomed Res Ther. 2016; 3(6), doi: 10.7603/s40730-016-0029-1.
60. Vetere A, Choudhary A, Burns SM, et al. Targeting the pancreatic beta-cell to treat diabetes. Nat Rev Drug Discov. 2014; 13(4): 278-289, doi: 10.1038/nrd4231, indexed in Pubmed: 24525781.

61. Wang $Y$, Chen $X$, Cao W, et al. Plasticity of mesenchymal stem cells in immunomodulation: pathological and therapeutic implications. Nat Immunol. 2014; 15(11): 1009 1016, doi: 10.1038/ni.3002, indexed in Pubmed: 25329189.

62. Xie Z, Hao H, Tong $C$, et al. Human umbilical cord-derived mesenchymal stem cells elicit macrophages into an anti-inflammatory phenotype to alleviate insulin resistance in type 2 diabetic rats. Stem Cells. 2016; 34(3): 627-639, doi: 10.1002/stem.2238, indexed in Pubmed: 26523620.

63. Xu X, D'Hoker J, Stangé G, et al. Beta cells can be generated from endogenous progenitors in injured adult mouse pancreas. Cell. 2008; 132(2): 197-207, doi: 10.1016/j. cell.2007.12.015, indexed in Pubmed: 18243096.

64. Zhang M, Lin Q, Qi T, et al. Growth factors and medium hyperglycemia induce Sox9+ ductal cell differentiation into beta cells in mice with reversal of diabetes. Proc Natl Acad Sci U S A. 2016; 113(3): 650-655, doi: 10.1073/ pnas.1524200113, indexed in Pubmed: 26733677. 